\title{
Online Shopping Behavior in Case of Apparel Product: Comparative Analysis between Japanese and Chinese University Students
}

Yu LI $\mathbf{L}^{1}$

Takeshi NAKAYAMA²

\begin{abstract}
With the increasing popularity of the EC (e-commerce) market, more and more consumers' consumption approaches have shifted from physical stores to online shopping.

Due to the different popularity of networks in various countries, there are also differences in the products and frequencies of online purchases.

At the same time, the network usage rate of the young people in Japan and China has reached more than 90\%, with college students around 20 years old accounting for the highest percentage.

Therefore, this paper focused on the college students' online purchase of clothing, and compared the consumption behaviors of Japanese and Chinese college students to explore the characteristics of Japanese and Chinese college students consumption behaviors.

After summarizing the theoretical research in the past, based on the online sales of clothing, we conducted a questionnaire survey among college students in Japan and China from the perspective of Marketing Mix.

The results show that when the college students in Japan and China purchase clothing, there was a big difference in (1) purchase channel, (2) commodity price, (3) commodity quality and (4) network comments.
\end{abstract}

Keywords: apparel product, online purchasing behavior, marketing mix, university students, comparative analysis

JEL clasifications: D2, D4, D9

DOI: $10.24818 /$ RMCI.2019.4.437

\section{Introduction}

According to OECD (2011), e-commerce can be defined generally as the sale or purchase of goods or services, conducted over computer networks by methods specifically designed for the purpose of receiving or placing of orders. On the other

\footnotetext{
${ }^{1} \mathrm{Yu}$ Li, Yokohama City University, Graduate School of International Management, Japan, e-mail: liyu6262@gmail.com

2 Takeshi Nakayama, Ph.D., Professor, Yokohama City University, Graduate School of International Management, Japan, e-mail: nakayamastudyoffice@gmail.com
} 
hand, Laudon \& Traver (2014) described that e-commerce refers to digitally enabled commercial transaction between and among organization and individuals.

EC in Japan began in the circulation industry by the amendment to "Public Electrical Communication Law" in 1982 and the implementation of the "Electronic Communication Business Law" in 1985, taking the opportunity liberalization of data communication among enterprises. In particular, the Internet was popularized in the general family in the late 1990s, the use of the search engine began in 2000, and the Japanese BtoC-EC, which started with the emergence of Amazon, grew rapidly (Kouno, 1999). According to the survey conducted by NRI (2018), the utilization rate of online shopping and the average number of uses per year continue to increase substantially. Online shopping utilization increased from $49 \%$ in 2015 to $58 \%$ in 2018, with an increase of about 10 percentage points. NRI also pointed out that compared with the 2015 survey, the users' average number of uses has increased, especially for the young people, and the number of uses for all users has increased from 14.8 times/year to 19.8 times/year.

On the other hand, an online mail-order demonstration website called "Jian gang" was born in 1997 as the in first China's EC, and the term online shopping was born the same year. So, in 1998, online mail order began in China (Yasumoto, 2005). In 2006, there were only 3,357 online shopping users in China, but the "43rd Statistical Report on Internet Development in China" published on February 28th by CNNIC (2019) shows that, as of December 2018, online shopping users increased by $14.4 \%$ year-on-year, reaching 610.11 million. Nearly $70 \%$ of netizens use this service, exceeding 600 million people for the first time. Among them, the number of people who shop online through mobile terminals such as smart phones is 591.91 million. The main development factors of China's EC are: (1) China's economic growth and consumption capacity improvement, (2)the improvement of network infrastructure, (3) the increase in network users, (4) the continuous expansion of online retail sales, (5)the increase in types and quantities of online shopping products, (6) the emergence of new companies entering the market such as "Baidu", and (7) the improvement in online shopping environments such as settlement, logistics, and CRM.

At present, the world BtoC-EC market size is growing year by year. In 2017, China has an absolute advantage in the size of the EC market and has grown by more than 30\% compared to 2016. Although Japan ranks fourth in the world in terms of market size, it had a growth rate of only $6 \%$ compared with the previous year (METI, 2017). In the EC markets of Japan and China, the number of consumers moving from physical stores to online shopping is increasing. Because there is a difference in the popularity of the Internet in each country, it is necessary to clarify the characteristics of Japanese and Chinese consumers' online purchase behaviors. This paper took Japanese and Chinese college students as research subjects to compare their consumption behaviors using the Internet to purchase clothes to clarify the characteristics of Japanese and Chinese college students' consumption behavior. 


\section{Literature Review}

\subsection{Consumer behavior and online shopping}

The theoretical study of consumer purchase behavior begins with the perspective of economics. According to the paper by Shiota (2002), the theoretical research on consumer purchase behavior is based on the consumer preference theory or consumer demand theory developed in the field of microeconomics. From the study of Matue \& Matumura (2013), the method of economics is based on the consumer's economic man model to make purchasing decisions from the evaluation of an independent theoretical framework on the basis of reasonable and sensible calculations, and consumers consume for maximum utility according to their own hobbies and the acceptable price.

However, economic theory ignores consumers' different responses to information and does not consider consumer demand and motivation as factors that influence consumer behavior. With the establishment of the mass consumer market, it is difficult to explain consumer actions using traditional theories, so the existence of the Interdisciplinary Approach method is particularly important (Bi, 2016).

\subsection{Japanese and Chinese consumers: Online purchase behaviors}

After entering the 21st century, research on information search through the Internet has become popular. The use of the Internet to search for information has attracted most attention. In 1990 and 2000, surveys were conducted to car buyers. The survey results show that the Internet has attracted the same level of attention as other sources of information, and that younger consumers with higher educational background are more likely to use the Internet when searching for information (Lee \& Talukdar, 2003).

Kimura (2005) believes that there are two main reasons hindering the success of Japanese online stores: the first is consumer's uneasiness about online transactions. This is due to the time and space distance between the seller and the buyer in the delivery and payment of goods; the second is the network itself, as well as the problems and uneasiness about its characteristics. The most representative problem is the disclosure of private information.

Lin (2006) pointed out the shortcomings of Japanese online stores: first, you cannot directly confirm the goods. If you are shopping online, you cannot directly confirm the product, so you can only rely on the picture or the manual for the product information. Although this does not matter for the products that are being used every day, online shopping for clothing and other products tend to be given up, because of the uneasiness of color, shape, feel, size and other factors. Second, while online users are expanding, there are still a limited number of consumers who regularly purchase products or services online.

An (2012) described the obstacles of Internet shopping (hereinafter referred to as "e-shopping") for Japanese clothing products. "E-shopping brings various

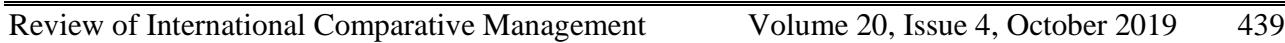


benefits to not only enterprises, but also consumers in terms of rationality and convenience and thus is increasingly expected to develop in the future. However, the problem that consumers' purchased goods cannot be directly confirmed during eshopping is still the core problem that hinders the development of e-shopping. Consumers may be more sensitive to purchase risks, especially when purchasing apparel items that are popular and aesthetically pleasing."

According to the research by Lei \& He (2008), the slow progress of China's traditional retail industry may be one of the factors that promote the development of online retail. Department stores had played an important role in the development of the retail industry by the 1950s. Since the 1950s, the implementation of China's planned economy has hindered the healthy development of the retail industry. In 1992, China began economic reforms, and the circulation industry entered a development track. However, China's retail industry has been on the right track for a short time, so the existing traditional retail industry cannot fully cover the country, which means that it cannot meet the needs of consumers. Therefore, there is still a large space for the development of online shopping in China.

Wang (2011) pointed out that China attaches great importance to the education of EC (e-commerce) talents. Since 2001, the EC discipline has been established in universities. The EC program was established in 180 universities in China in 2004, and was increased to 1004 universities in 2012. At present, educational institutions, including graduate schools, universities, and communication education, have formed an EC education system. After years of development, EC has become a mature comprehensive discipline. After a large number of EC graduates enter the companies, they use their professional knowledge to contribute to the development of online shopping in China.

Takaguchi (2017) pointed out the reasons for the growth of China's EC market, such as the "Singles' Day" to promote online shopping consumption, the integration of online and offline shopping, especially the changes in Chinese consumer awareness and the growing disposable income of the middle class or richer people.

Guan(2018) emphasized that China has developed a digital economy with individuality by making use of the advantages of latecomers and the huge domestic market. First, although the amount of each transaction is small, network companies are actively occupying the long tail market consisted of a large number of consumers. In addition, while network companies are in close communication with consumers, they can maximize the use of external resources and provide goods and services through cooperation with other companies. At the same time, new technologies such as big data and AI are actively applied to the commercial field.

\subsection{Japanese and Chinese consumers: Comparisions of online purchase behaviors}

Niita (2008) commented on the future challenges of Uniqlo in the Chinese market. The problem facing Uniqlo is to re-adjust the $90 \%$ sewing system in China. 
For Uniqlo, which considers global sales in the future, expanding production bases outside China is indispensable. Due to concerns about rising labor costs in China, it is very important to develop production bases with lower costs as early as possible. Moreover, how to maintain the balance between fashion and practicality, how to control the risks that must be borne, and how to improve brand power and visibility are also important issues.

Jin (2016) compared why there is such a big difference in the business form of EC in China and Japan. Japanese physical store service is attentive and you can enjoy comfortable shopping. In contrast, China's physical store service attitude needs to be improved, and there is still a big gap with Japan. For the Japanese, window shopping has become a way of life. The Chinese have not yet formed the habit of spending time leisurely. The elderly are more willing to drink tea at home, and they have no intention of going to the shopping street to spend money on coffee.

In Hirose's (2018) paper, the following discussion was made on the similarities and differences between consumption attitudes between Japan (Tokyo Area) and China (Shanghai, Beijing). According to its content, the consumer attitude of Chinese consumers is to achieve synchronization with others or to obtain differences through personality trends, fashion trends, brand trends, etc., and to pay more attention to the so-called relationship consumption with others. However, from the perspective of social consumption and risk management consumption, Chinese consumers always like to make rational consumption and actively control risk.

Why is online shopping in the apparel sector not as popular as expected in Japan? On the other hand, why is online shopping in the apparel sector popular in China? As seen from the summarization of the previous research, Niita (2008) first analyzed the differences in the way Japanese clothing companies operate in the Japanese and Chinese markets. Jin (2016) compared the online sales methods of Japan and China, pointing out that the reason for the development of online shopping in China is (1) reception attitude (2) lifestyle. In addition, Hirose (2018) also found similarities and differences in the attitudes between Japanese and Chinese consumers. In recent years, with the popularity of the Internet and smart phones, research on consumer behavior with the subjects of online shopping, SNS, and word of mouth has gradually increased. However, there is relatively little international comparison of clothing purchase behaviors, especially between Japan and China. Therefore, by comparing and analyzing the online shopping behaviors of Japanese and Chinese college students, it is hoped that the characteristics of online shopping consumption behavior in the two countries can be found. In this paper, we proposed the following hypothesis from the perspective of marketing mix (4p).

\section{Hypotheses}

H1: Chinese college students have a higher proportion of online purchase of clothing goods than Japanese college students.

This hypothesis is based on the perspective of Place. In the China College students Observation Report published by the Chinese research company iResearch 
(2018), the most frequently used channel for Chinese female college students to purchase cosmetics is "online purchase", accounting for $63.6 \%$. It is speculated that the proportion of Chinese college students buying clothing online may exceed half. Therefore, $\mathrm{H} 1$ was proposed.

H2: When buying clothing online, Chinese college students have a higher rate of purchasing low-priced goods than Japanese college students.

This hypothesis is based on the perspective of Price. The average annual living expenses of Japanese college students in 2016 (excluding nighttime) was about 43,000 yuan, and the average monthly average was about 3,613 yuan. Including residential and day students, "other daily expenses" such as clothing and mobile phone fees averaged about 9,427 yuan (Japan Economic News, 2016). On the other hand, the "Mycos Student Consumption Values and Asset Use Survey 2016" conducted by Mycos (2016), an information service company of higher education, shows that the average monthly consumption of Chinese college students was about 1212 yuan. It can be seen that the monthly living expenses of Chinese college students are less than those of Japanese college students. Therefore, H2 was proposed.

H3: When purchasing clothing online, Chinese college students pay more attention to product quality than Japanese college students.

This hypothesis is based on the perspective of Product. Products are not just hardware, but also hardware-related software, that is, goods and services. If you are shopping online, you cannot directly confirm the product, so the product information can only be obtained from pictures or instructions. However, when buying clothes, Japanese consumers are less likely to buy online due to many uneasy factors such as color, shape, feel, and size. On the other hand, for some consumers who shop online, the big motivation is that they can buy goods that are not available in stores near their place of residence. Chinese college students generally live in university dorms, and there are no shopping centers around the universities, so the tendency to shop online is relatively high. However, from the quality assurance of shopping websites, China still has a lot of room for improvement compared to Japan. Therefore, H3 was proposed.

H4: When purchasing clothing online, Chinese college students refer to online network comments more than Japanese college students.

This hypothesis is based on the perspective of Promotion. Promotion mainly refers to advertising, sales, public relations, direct marketing and so on. The KPMG Japan Survey (2017) shows that about 30\% of customers submit online feedback on commodities, and Asia accounts for $43 \%$ of this, which is higher than the global average. On the other hand, consumers in Australia, Japan, and most Western European countries have a lower percentage of comments. But the rate of young consumers posting comments online is high, and this trend will continue even if they get older. It is speculated that Chinese college students have a higher rate of reference network evaluation than Japanese college students. Therefore, H4 was proposed. 


\section{Methodology}

In order to verify the above four hypotheses, this paper set up the questionnaire survey questions from the perspectives of the frequency of use of online clothing purchase by Japanese and Chinese college students, the importance elements, and the reasons for use, and implemented a questionnaire survey. The respondents were Japanese college students (172 people with effective answers) and Chinese college students (223 people with effective answers). Among the respondents of Japanese college students, the proportion of the freshmen was the highest, while various grades of Chinese college students accounted for a similar proportion among the respondents. In addition, there were more girls in both Japanese and Chinese college respondents. Each issue was assessed by a five-stage Likert Scale. In the analysis, SPSS was used, and the hypothesis was verified by using statistical methods such as description statistics, T test, and chi-square test.

Table 1. Demographic profile of respondents

\begin{tabular}{|c|c|c|c|c|}
\hline \multirow[b]{3}{*}{ Gender } & \multicolumn{2}{|c|}{ China } & \multicolumn{2}{|c|}{ Japan } \\
\hline & Frequency & Percentages & Frequency & Percentages \\
\hline & & & & \\
\hline Male & 38 & 17.0 & 72 & 41.9 \\
\hline Female & 185 & 83.0 & 100 & 58.1 \\
\hline \multicolumn{5}{|l|}{ Grade } \\
\hline Freshman & 54 & 24.2 & 112 & 65.1 \\
\hline Sophomore & 54 & 24.2 & 27 & 15.7 \\
\hline Junior & 56 & 25.1 & 30 & 17.4 \\
\hline Senior & 59 & 26.5 & 3 & 1.7 \\
\hline Total & 223 & 100.0 & 172 & 100.0 \\
\hline
\end{tabular}

Source: Author's calculations

\section{Results}

For H1, the question set in the questionnaire is: When you buy clothing, do you mainly buy it online, or mainly in the store? 1. Mainly purchase online 2 . Mainly purchase in the store. According to the results of the survey, 176 Chinese college students buying online, accounting for $88.9 \%$. Only $22 \%$ of Japanese college students answered the online purchase of clothing. In order to find out whether there is a statistical difference in the results, a chi-square test (Table 2) was implemented. Since the $\mathrm{P}$ value on both sides $=0.000<0.05$, there was a significant difference in the results. It can be seen that there were significant differences in the purchase channels between college students in Japan and China when purchasing clothing. Chinese college students were more inclined to buy clothing online than Japanese college students. So H1 was verified. 
Table 2. The Chi-square test of the purchase channels

\begin{tabular}{ccccccc}
\hline & $\mathbf{N}$ & $\%$ & Chi-square & p-value & $\begin{array}{l}\text { 95\% C.I. } \\
\text { (Lower) }\end{array}$ & $\begin{array}{c}\text { 95\% C.I. } \\
\text { (Upper) }\end{array}$ \\
\hline China & 176 & $88.9 \%$ & 169.878 & .000 & .21901 & .28967 \\
Japan & 22 & $11.1 \%$ & & & & \\
\hline
\end{tabular}

Source: Author's calculations

For $\mathrm{H} 2,3,4$, the questions set in the questionnaire is: Please select the level of importance for the price, the quality of the product, and the praise of netizens when you purchase clothing online (low importance 1 to high importance 5). From the responses of Chinese college students, it can be seen that the average value of emphasis on price was 3.34, while the average value of Japanese college students was 3.94. According to the test results of t-test of price importance when Japanese and Chinese consumers purchase clothing goods online (Table 3), the probability of validity of the t-test (both sides) $=0.000<0.05$, so there was a significant difference on average. So $\mathrm{H} 2$ was verified.

Table 3. When purchasing clothing online, the t-test of price importance

\begin{tabular}{lcccccc}
\hline & N & Mean & SD & t & df & $\begin{array}{c}\text { Sig. } \\
\text { (2-tailed) }\end{array}$ \\
\hline China & 223 & 3.34 & .869 & 6.190 & 393 & .000 \\
Japan & 172 & 3.94 & 1.074 & & & \\
\hline
\end{tabular}

Source: Author's calculations

When purchasing clothing online, the average value of Chinese college students' attention to quality reached 4.33 , while the average value answered by Japanese college students was 3.83. According to the results of t-test on quality importance (Table 4 ), the validity probability of t-test (both sides) $=0.000<0.05$, so there was a significant difference on average. In other words, when purchasing clothing online, Japanese and Chinese college students had significant differences in the importance they attached to clothing quality. Therefore, $\mathrm{H} 3$ was verified.

Table 4. When purchasing clothing online, the t-test of quality importance

\begin{tabular}{lcccccc}
\hline & N & Mean & SD & t & df & $\begin{array}{c}\text { Sig. } \\
\text { (2-tailed) }\end{array}$ \\
\hline China & 223 & 4.33 & .714 & & 293.476 & \\
Japan & 172 & 3.83 & 1.015 & 5.453 & & .000 \\
\hline
\end{tabular}

Source: Author's calculations 
When purchasing clothing online, the average value of online word-of-mouth in Chinese respondents was 4.12, and the average value of Japanese college students was 3.25. According to the test results of t-test on the importance of Internet word-ofmouth (Table 5), the probability of t-test validity (both sides) $=0.000<0.05$, so there was a significant difference in the mean. It can be seen that there were differences between the students of Japan and China in terms of comments about netizens' purchases of clothing. Therefore, $\mathrm{H} 4$ was verified.

Table 5. When purchasing clothing online, the t-test of Internet word-of-mouth

\begin{tabular}{lcccccc}
\hline & N & Mean & SD & t & df & $\begin{array}{c}\text { Sig. } \\
\text { (2-tailed) }\end{array}$ \\
\hline China & 223 & 4.12 & .841 & 8.376 & 303.457 & .000 \\
Japan & 172 & 3.25 & 1.140 & & & .000 \\
\hline
\end{tabular}

Source: Author's calculations

\section{Conclusion}

This paper took Japanese and Chinese college students as the subjects, conducted a questionnaire survey on the consumption activities of online clothing purchase, and compared and analyzed the collected data. Judging from the survey results, there were some differences in the opinions and purposes of online shopping between Japanese and Chinese college students in the purchase of clothing goods, and these differences had a greater impact on their online shopping. In summary, the above four verification results are explained below.

(1) In terms of Place, Japanese college students had a lower proportion of online clothing purchases. On the other hand, the proportion of Chinese college students using online shopping was higher. Based on this result, it is speculated that the habit of purchasing clothing online in China will become more common in the future. (2) In terms of Price, Japanese college students valued clothing prices, but the frequency of online purchases was low. On the other hand, China's online clothing goods were cheaper than that in the physical stores, so the proportion of Chinese college students buying low-priced clothing online was high. (3) In terms of Product, since the products produced in Japan always leave people with a highquality impression, Japanese students did not pay much attention to quality. On the contrary, Chinese college students attached great importance to the quality of clothing. It can be seen that if China's online sales in the future are to seek better development, it is necessary to improve the attractiveness to customers and improve their level of competition by ensuring the quality of goods. On the other hand, if Japan's online sales want to change, it is particularly important for online sales entities to have the technical development ability to meet the consumer's demand for the size, color, design and other personal requirements of the clothing. (4) In terms of promotion, the ratio of Japanese college students' reference to online 
reviews was low. In contrast, Chinese college students were more concerned about consumer comments on the Internet. In the future, in order to attract Chinese consumers' purchase intentions in the process of online sales, it is still necessary to improve the reputation of online comments.

In today's Japan and China, almost all college students have smartphones, but there are still big differences in the consumption behavior of online clothing purchases. Therefore, it is speculated that there may be various differences in the consumption behavior of college students in other countries when purchasing clothing goods. In the future development of apparel enterprises, it is necessary to investigate the differences in the purchasing behavior of consumers in these different countries in order to more accurately determine the marketing strategy of physical stores and the Internet, so as to obtain significant competition advantage in the international market.

\section{References}

1. An, C. (2012). Study on the perception risk structure in e-shopping of clothes: Focusing on consumer comparison in Japan and Korea (Irui shouhin eshoppingu ni okeru chikakurisuku kouzou ni kansuru kenkyuu: Nihon to Kankoku no shouhisha hikaku wo chuushin ni). Direct marketing review: Journal of the Academic Society of Direct Marketing. Volume 11: The Japanese direct marketing academic meeting, pp. 20-37.

2. Bi, C. (2016). Study on consumer purchasing behavior of the online shopping market. Papers of the research society of commerce and economics (Netto tsuuhan shijouu ni okeru shouhisha koubai koudou ni kansuru kenkyuu. shuudou shougaku). 57(1), pp. 97-124.

3. Brian, T., Lee, M., \& Talukdar, D. (2003). "The impact of the Internet on information search for automobiles," Journal of Marketing Research, 40(2), pp.193-209.

4. CNNIC. (2019). Statistical report of Chinese Internet Development (Zhong Guo hulianwang fazhan tongji baogao). [online] Available at: <http:// www.cnnic.net.cn/> [Accessed 3 June 2019].

5. China.org.cn. (2017). The average monthly consumption of Chinese university students is 1212 yuan (Chuugoku daigakusei no tsukiheikin shouhigaku wa 1212 gen). [online] Available at: <http://www.japanese.china.org. cn/business/txt/2017-03/02/content_40394340.html/> [Accessed 19 September 2018].

6. Guan, Z. (2018). The digital economy in China that is making a breakthrough: Focusing on the development of the Internet industry. New China economy: Chinese industry and companies (Yakushin suru Chuugoku ni okeru digital economy - Internet sangyou no hatten wo chuushin ni -. Chuugoku keizai shinron: Chuugoku no sangyou to kigyou). [online] Available at: <http://www.rieti.go.jp/users/china-tr/jp/181120sangyokigyo.html /> [Accessed 18 June 2019]. 
7. Hirose, T. (2018). Consumption culture and consciousness in Chinese consumer society - Based on a result of the statistical survey in 2 cities of Shanghai and Pekin. The Journal of Applied Sociology (Chuugoku shohishakai no shohibunka to ishiki - Shanghai - Pekin 2 toshi no toukei chousa no kekka wo motoni. Ouyou shakaigaku kenkyu). No.60, pp. 91-105

8. iResearch. (2018). A report on the consumption trend of Chinese university students (Daily consumption). Insight report on Chinese university students (Chuugoku no daigakusei shouhi doukou report- Nichijou shouhihen. Chuugoku daigakusei dousatsu report). [online] Available at: <http://www. chinapass.jp/2018/reports/chinese-university-student-comsumption/> [Accessed 17 April 2019].

9. Jin, N. (2016). The reasons why online shopping in Japan is not so popular, compared with China (Nihonde Internet shopping ga Chuugoku hodo moriagaranai wake). [online] Available at: <http:// j.people.com.cn /n3/2016/1123/c94473-9145756.html/> [Accessed 4 July 2019].

10. Kimura, T. (2005). Introduction to Internet marketing (Internet marketing nyuumon). Tokyo: Nikkei Publishing.

11. Kouno, K. (1999). International e-commerce practices (Kokusai denshi shoutorihiki no jissai). Tokyo: Tokyo Keizai.

12. KPMG Japan. (2017). The actual state of consumers' online shopping behaviors (Online shopping ni okeru shouhisha koudou no jittai). [online] Available at: <http://kpmg.com/jp/online-consumers/> [Accessed 19 September 2018].

13. Laudon, K., \& Traver, C. (2014). E-commerce 2014, 10th edition. London: Pearson.

14. Lei, L., \& He, X. (2008). Introduction to e-commerce. Wuhan University Press.

15. Lin, Y. (2006). Study on the consciousness research of internet shopping by the spread of computers. (Computer fukyu ni yoru tsushin-hambai no ishiki ni kansuru kenkyu). [pdf] Available at: <www.sonoda-u.ac.jp/dic/ kenkyu/2006/39.pdf> [Accessed 17 October 2018].

16. Matsue, H., \& Matsumura, H. (2013). Modern consumer behavior theory (Gendai shohisha kodou ron). Tokyo: Sosei Sha.

17. METI. (2017). Survey of infrastructure development status for data-driven society in Japan (Heisei 28-nendo Wagakuni ni okeru data kudou-gata shakai ni kakaru kiban seibi denshi shoutorihiki ni kansuru shijou chousa). [pdf] Available at: <www.meti.go.jp/policy/it_policy/statistics/outlook/h28 report2.pdf $>$ [Accessed 30 May 2019].

18. Niita, T. (2008). Business system innovation of SPA (2)-Case study of UNIQLO and Zara. Studies in business administration (SPA no business system kakushin (2) - UNIQLO to Zara wo jirei toshite. Bunkyou gakuin daigaku keiei gakubu ronshuu), 18(1), pp. 67-81.

19. NRI. (2018). Survey of 10,000 residents (8th) (Seikatsusha 1 mannin ankeeto chousa (Dai 8-kai-me)). [pdf] Available at: <www.nri.com//media/Corporate/jp/Files/PDF/knowledge/report/cc/mediaforum/2018/forum27 2.pdf> [Accessed 22 May 2019]. 
20. OECD. (2011). OECD guide to measuring the information society. OECD.

21. Okumoto, K., \& Hayashida, H. (2004). Introduction to marketing (Marketing gairon). Tokyo: Chuo University Press.

22. Shiota, S. (2002). Theory and analysis of consumer behaviors (Shouhisha koudou no riron to bunseki). Tokyo: Chuokeizai-Sha Holdings.

23. Takaguchi, K. (2017). Newsweek Japan. [online] Available at: <http://www.newsweekjapan.jp/writer/takaguchi/> [Accessed 15 April 2019].

24. Wang, J., \& Matsuura, Y. (2011). Contemporary Chinese consumer culture: Branding, advertising and media (Gendai Chuugoku no shouhi bunka Burandingu $\cdot$ koukoku $\cdot$ media). Tokyo: Iwanami Shoten Publishers.

25. Yasumoto, T. (2005). Consideration of the development and issues of online shopping. Tottori University of environmental studies department of information systems project research report (Tottori kankyou daigaku jouhou system gakka purojekuto kenkyu houkokusho), pp. 1-35. 